\title{
A Multi-layered Minority: Hazara Shia Women in
} Pakistan

Shia account for approximately 10-15 per cent of the Muslim population in Pakistan, which has a largely Sunni Muslim population. Anti-Shia violence, led by extremist militant groups, dates to 1979 and has resulted in thousands killed and injured in terrorist attacks over the years. Hazara Shia, who are both an ethnic and a religious minority, make an easy target for extremist groups as they are physically distinctive. The majority live in Quetta, the provincial capital of Balochistan in central Pakistan, where they have become largely ghettoised into two areas as result of ongoing attacks. Studies on the Hazara Shia persecution have mostly focused on the killings of Hazara men and paid little attention to the nature and impact of religious persecution of Shias on Hazara women. Poor Hazara women in particular face multi-layered marginalisation, due to the intersection of their gender, religious-ethnic affiliation and class, and face limited opportunities in education and jobs, restricted mobility, mental and psychological health issues, and gender-based discrimination.

\section{Key messages}

- Continuous exposure and vulnerability to violence and ongoing terror attacks as well as the consequences of trying to stay safe (constrained mobility especially for women) has significant economic as well as psychosocial impact for both Hazara Shia men and Hazara Shia women.

- For Hazara Shia men, safety and security is the number one concern and they shoulder the responsibility for both protecting and providing for their families.

- For Hazara Shia women, the threat of violence and harassment has resulted in being constrained by their own community, limiting their access to quality education and job opportunities.

Violence against Hazara Shia has a knock-on effect: non-Hazaras are fearful of employing them for fear of becoming targets themselves.

\section{Context}

The Hazara Shia are one of Pakistan's most persecuted religious minorities. According to one of the Vice-Chairs of the Human Rights Commission Pakistan, the country's leading human rights watchdog, nearly 1,000 Hazaras were killed in sectarian violence between 2009 and 2014, and there have been more attacks claiming more lives since then. Anti-Shia violence dates back to the 1979 Iranian [Shia]

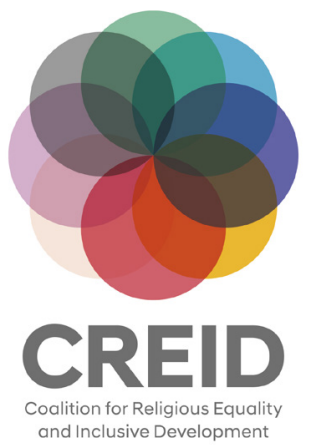


Revolution when the Pakistani military formed the anti-Shia militant group, Sipah-e-Sahaba, with the help of Saudi funding, to contain the influence of the revolution beyond Iran's borders. Violence against Shias intensified when Pakistan became an ally of the US in its 'war on terror' in the early 2000s, which saw a crackdown against al-Qaeda in northern parts of the country. For extremist groups like the Lashkare-Jhangvi (LeJ), an anti-Shia terror group affiliated with al-Qaeda, and the Tehrik-e-Taliban Pakistan (a Pakistan-focused religious militant group), killing Shias is necessary to make Pakistan 'pure' from 'heretics'. They call for the extermination of Shias 'from every city, every village, and every nook and corner of Pakistan'.

Hazara Shias were an easy target for terrorists as they are more recognisable due to their Mongolian physiognomy. Continued attacks against them has resulted in mass migration (around 30,000 Hazaras migrated from Balochistan between 2009 and 2014, according to one estimate) or ghettoisation into two areas of Quetta, Hazara Town and Mari Abad. Military and paramilitary checkpoints were deployed in Quetta after 2003 when the law and order situation worsened. Although meant to protect Hazaras, these checkpoints have become a source of daily harassment and humiliation for the community. Hazaras are routinely searched and asked to show their identity cards and to state the purpose of their visit, despite knowing that they are

\section{"[In Pakistan]}

Sunni extremist groups... call for the extermination of Shias 'from every city, every village, and every nook and corner of Pakistan' "

\section{Methodology Note \\ Using participatory ranking}

The research study combined participatory ranking methodology with Focus Group Discussions (FGDs). Participatory ranking was used with participants to identify the challenges and the scope and intensity of their effect. The participatory ranking was used with 44 Hazara Shia participants across six FGDs. Two FDGs were carried out with teenage girls (aged 14-16 years), two with women under the age of 35 and two with men (aged 16-35 years and 35+ years). Additionally, eight women over the age of 35 were interviewed separately to reduce the risk of Covid-19 transmission. In total, the research involved 32 women and girls and 12 men. Participants identified all the challenges facing Hazara Shia women and girls and then individually ranked these challenges to indicate which challenges they thought were most prevalent. The ranking was analysed for trends, frequency and preferences of each individual, as well as being aggregated to reveal group trends. These challenges and their ranking were discussed within each FGD and during the separate interviews. Most of the participants were from the lower end of the socioeconomic strata of the Hazara community including the women who lost their family members in the anti-Shia violence.

\section{Researchers from the same community as participants}

The participatory ranking process and focus groups were led by a researcher who not only came from the Hazara Shia community herself, but also had a personal journey of surviving the emotional and mental trauma of terrorism. The involvement of a researcher, who is not only trustworthy but also shares similar experiences in life, was essential for empowering research participants to speak candidly about their experiences. A conscious reflexive process with two other researchers, also Shias but not Hazaras and not based in Pakistan, aimed to present data and findings in the best possible objective manner whilst remaining mindful of their shared religious identity. 
returning to their homes. While Hazara men have suffered hugely, being the main target of militants, the challenges that women have faced - such as being widowed, restriction on mobility, and the issue of 'honour' for young Hazara girls - have largely remained unaddressed. While some level of gender-based discrimination is no surprise for a semi-tribal and disadvantaged region of Pakistan, it is vital to understand how Hazara women also face gender-based discrimination by Hazara men themselves. A lot of this discrimination is security induced, where cultural norms that regard women and girls as the honour of families intersect with increased insecurity in the wake of terrorist attacks on the community and the consequent threat of physical and emotional harm to females.

\section{Key findings}

The top six challenges identified by research participants in the aggregate ranking were as follows:

1. Barriers to education, particularly in relation to access to higher/ tertiary education;

2. Constrained economic conditions and limited livelihood opportunities, specifically a lack of job opportunities due to restricted mobility and the security threat;

3. Absence of religious freedom, particularly related to discrimination when out in public, such as people refusing to share a space with them;

4. Ongoing threat to safety and security, especially the immense risk involved when trying to leave their restricted neighbourhood;

5. Impact on mental and physical health, primarily the day-to-day anxiety that comes from constantly living in fear for the male members of the family who regularly leave the restricted neighbourhood for work;

6. Reinforced gender discrimination, particularly in relation to the belief that women and girls are responsible for the family and community honour.

It is worth noting that the men involved in the research ranked 'safety and security' as the number one threat to Hazara Shia men. Their acute awareness of this issue is potentially linked to the heavy responsibility they face to protect their families and community from increasing securitisation threats. The women and girls in the study did recognise this responsibility, which they described as facing pressure to go out and provide for the family, something which put them at an increased risk of violence.

Education was a particularly prominent issue for the girls and young women participants who complained of discriminatory attitudes in educational institutes both by non-Hazara and non-Shia teachers and students. While Hazaras are generally supportive of education for women and girls, it became clear during the research that the fear of Hazara Shia girls and young women experiencing violence and harassment on their way to and from school or college has led to the Hazara Shia community restricting Hazara Shia girls and young women, leading to increased dropout rates. This was linked by the
"While Hazaras are generally supportive of education for women and girls... the fear [that they will] experience violence and harassment on their way to and from school or college has led ... to increased dropout rates" 
participants to the concept of 'honour' and how women and girls within the Hazara Shia community are seen as holding the community's 'honour'. If they are violated then the whole community loses its honour. This is one example of religious discrimination intersecting with gender discrimination within the community.

Discussions around the other challenges included how the overall security situation has permanently and severely affected the economic condition of the community, and the decline of religious freedom and participation due to fear of targeted killing, terrorism, and attacks and the impact of being born into the violence and ghettoisation of the community on Hazara Shia young women and girls' mental health. Although both men and women experience lack of job opportunities due to restricted mobility, security risk and stereotypes against the community, as well as non-Hazaras being too fearful to employ Hazara men and women in case their presence makes them a target, Hazara women also face policing in their job opportunities from their community, limiting them to jobs that mean they won't interact with the non-Hazara community.

\section{Policy recommendations}

Based on the experiences shared during the FGDs and interviews, and the knowledge of the researcher as a member of the Hazara Shia community in Pakistan, the following recommendations are made to improve the situation of Hazara Shia women and girls:

- Federal and provincial governments must safeguard the Hazara community, enabling them to practice and express their cultural and religious identity without fear.

- The law and order/security situation must be improved to enable Hazaras to live a normal secure life by preventing anti-Shia militant organisations to operate in Balochistan.

- A mechanism must be introduced to sensitise and hold accountable those who are involved in the bullying and harassment of Hazaras (both men and women) at security checkpoints in the Hazara localities.

- There must be awareness-raising and sensitisation programmes introduced that are aimed at educating government officers and teachers in educational institutes about the Shia faith, diversity and inclusion.

- There must be dedicated higher studies scholarships for Hazaras to address the drop-out rate of Hazara in education due to the violence against the community.

- Hazara women entrepreneurs need to be enabled with skills and livelihood developments, with incentives (interest-free loans and grants) for economically excluded Hazara women prioritised.

- Well-integrated psychosocial support programmes need to be introduced; prioritising women and girls whose families have been directly affected by violence. 


\section{Further reading}

Amman, M. (2020) 'Go in Disguise to Receive Medical Treatment' Religious Discrimination in Pakistan', Institute of Development Studies (Opinion)

Habib, R.; Sultan, S. and Changezi, S.H. (2020) 'Hazara Women: The Lynching That We Didn't Do', Institute of Developmeny Studies (Opinion)

Sultan, S. (2020) 'Dire Conditions for Hazara Shia Pilgrims During Covid-19 Quarantine in Pakistan: Six Women Share their Experiences', Institute of Developmeny Studies (Opinion)

Sultan, S. (2020) 'Why this Year's Ashura will be a Challenge for Quetta's Hazara Community' The Express Tribune

Sultan, S.; Kanwer, M. and Mirza, J.A. (2020) 'The Multi-Layered Minority: Exploring the Intersection of Gender, Class and Religious-Ethnic Affiliation in the Marginalisation of Hazara Women', in M. Tadros (ed.) Violence and Discrimination against Women of Religious Minority Backgrounds in Pakistan, CREID Intersection Series: Gender and Religious Inequalities, Brighton: Institute of Development Studies, DOI: 10.19088/CREID.2020.003

Tadros, M. (editor) (2020) Violence and Discrimination against Women of Religious Minority Backgrounds in Pakistan, CREID Intersection Series: Gender and Religious Inequalities, Brighton: Institute of Development Studies, DOI: 10.19088/CREID.2020.003

\section{Credits}

This policy brief draws on the CREID paper 'The Multi-Layered Minority: Exploring the Intersection of Gender, Class and Religious-Ethnic Affiliation in the Marginalisation of Hazara Women' by Sadiqa Sultan, Maryam Kanwer and Jaffer Mirza. It was compiled by Amy Quinn-Graham and edited by Emilie Wilson. It was produced as part of the Coalition for Religious Equality and Inclusive Development (CREID), a consortium funded by UK Aid from the UK government which provides research evidence and delivers practical programmes which aim to redress the impact of discrimination on the grounds of religion or belief, tackle poverty and exclusion, and promote people's wellbeing and empowerment.

The opinions expressed are those of the author and do not necessarily reflect the views or policies of IDS or the UK government.

CREID Policy Briefings are published by the Institute of Development Studies and aim to share key research findings and make practical recommendations for policymakers and donors.

(c) BY This is an Open Access publication distributed under the terms of the Creative Commons Attribution 4.0 International licence (CC BY), which permits unrestricted use, distribution, and reproduction in any medium, provided the original authors and source are credited and any modifications or adaptations are indicated.

\section{DOI: 10.19088/CREID.2020.011}

Institute of Development Studies, Brighton BN1 9RE, UK

$T+44(0) 1273606261$

$\mathrm{F}+44(0) 1273621202$

Ecreid@ids.ac.uk

Wwww.ids.ac.uk/creid

T@CREID_Dev

CREID partners

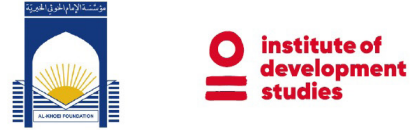

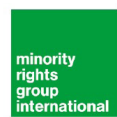

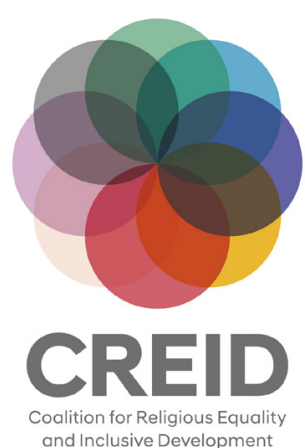

